\title{
Scorpionism in Brazil in the years 2000 to 2012
}

\author{
Guilherme Carneiro Reckziegel $\mathrm{l}^{1,2^{*}}$ and Vitor Laerte Pinto $\mathrm{Jr}^{3}$
}

\begin{abstract}
Background: Scorpionism is a serious public health problem in Brazil. Nationwide epidemiological analyses of scorpion stings are scarce. In this context, the present study aims to provide an epidemiological analysis of accidents involving scorpions in Brazil.

Methods: An analytical epidemiological study of the scorpion accidents reported in the Information System for Notifiable Diseases (SINAN) was conducted from 2000 to 2012 in Brazil.

Results: During this period, 482,616 accidents and 728 deaths were reported. The annual average incidence and mortality rates per 100,000 inhabitants were 19.6 and 0.030 , respectively, with annual average lethality rate of $0.16 \%$. The highest accident frequency was recorded in male subjects, aged 20-49 years, from September to December and in urban areas, except in the northern region of the country, where accidents were most frequent in June and July, and in rural areas. Males up to age 9 and rural areas were defined as an age group and area for greatest death risk, respectively.

Conclusions: Scorpionism in Brazil is a predominantly urban health problem that mostly affects people at an economically active age. The Northeast and Southeast hold the majority of cases and deaths, as well as the highest annual incidence and mortality averages, but the Central West and North presented the highest average annual lethality rates. The epidemiological changes described in this study highlight the need for intensifying health surveillance actions to prevent scorpion accidents in Brazil.
\end{abstract}

Keywords: Tityus, Scorpion sting, Epidemiological profile, Public health, Brazil

\section{Background}

Long ago scorpionism was recognized as a public health problem, being labeled by the World Health Organization (WHO) as a neglected health problem, and thus associated with poverty [1-7]. The current incidence of scorpionism is not known, because not all injured people seek medical attention. However, it is estimated that about 1 million accidents occur annually worldwide [8].

Although scorpionism surveillance activities began to be coordinated by the Brazilian Ministry of Health (MS) in 1988, only since 1997 have venomous animal accidents been reported in the Information System for Notifiable Diseases (SINAN), which is currently the official registry system for compulsory notification of health problems and diseases [9].

\footnotetext{
* Correspondence: guilhermereckziegel@gmail.com

'Programa de Pós-Graduação em Saúde Coletiva, Faculdade de Ciências da Saúde, Universidade de Brasília, Brasília, Distrito Federal, Brasil

${ }^{2}$ Programa Nacional de Controle de Acidentes por Animais Peçonhentos, Ministério da Saúde, Brasília, Distrito Federal, Brasil

Full list of author information is available at the end of the article
}

The incidence of accidents involving scorpions in Brazil has been increasing over the years [10]. Data collected by the National Program for Control of Accidents by Venomous Animals, in the period from 1990 to 1993, revealed about 8,000 accidents per year, with an average annual incidence of three cases per 100 thousand inhabitants. The main records were from the states of Minas Gerais and São Paulo, totaling approximately 50\% of notifications, but other states such as Bahia, Rio Grande do Norte, Alagoas and Ceará have been increasing the number of reports. The majority of cases were clinically mild, with a mortality rate of around $0.9 \%$, while most fatal accidents were associated with the specie Tityus serrulatus [10]. Between 1988 and 1999, there was an annual average of 6,267 accidents in Brazil [11].

The Brazilian scorpion fauna is quite large, consisting of about 131 species, 23 genera and four families [12]. The scorpions recognized for their medical importance in Brazil belong to the Buthidae family, genus Tityus, with four main species recognized for causing clinically serious accidents: Tityus serrulatus, T. stigmurus, T. bahiensis and 
T. obscurus (synonyms: T. cambridgei and T. paraensis) [1]. They are spread across all geographical regions of Brazil, with $T$. serrulatus (yellow scorpion) being the main cause of serious accidents [13].

Nationwide epidemiological analyses of the scorpion stings are scarce. In this connection, the present study aims to present an epidemiological analysis of accidents involving scorpions in Brazil, in the period from 2000 to 2012 .

\section{Methods}

An analytical epidemiological study of the scorpion accidents recorded in SINAN between 2000 and 2012 was conducted in Brazil. The databases were updated through February, 2014, with two versions of SINAN being used: SINAN - Windows version, from 2000 to 2006; and SINAN-Net version, from 2007 to 2012.

In accordance with federal decree n.1271, of June $6^{\text {th }}$, 2014, accidents with venomous animals are classified as requiring a notification to SINAN as a health problem. The Ministry of Health of Brazil (MS) describes each scorpion accident with clinical evidence of scorpion envenomation, with or without identification of the animal causing the accident [14]. The present study considered the total number of registered cases in SINAN as all the accidents having happened in Brazil.

Demographic data were obtained from the 2000 and 2010 censuses, and projections and interpolation for the years 2001-2009, 2011-2012 between censuses, from the Brazilian Institute of Geography and Statistics (IBGE) [15].

The fields of the Notification/Investigation SINAN Form (FNI) for accidents with venomous animals used in the study were: date of accident, date of death, gender, age, race/color, education, injured part of the body, place of the accident. The presentation of the "Education" field differs between the Windows and Net SINAN versions; therefore, it was standardized according to the Windows SINAN FNI in years of schooling. For this purpose, the variables of this field present in the Net SINAN FNI were characterized as: none, corresponding to illiterate; 1-3 years, corresponding to $1^{\text {st }}$ to $4^{\text {th }}$ incomplete elementary school (ES) grade; $4-7$ years, corresponding to $4^{\text {th }}$ full year of ES and $5^{\text {th }}$ to $8^{\text {th }}$ grade of incomplete ES; 8 or more years, corresponding to complete ES, incomplete high school, complete high school, incomplete higher education, or complete higher education.

In scorpion stings, local pain is an instant symptom [13,16-18]. Therefore, to adjust for the inconsistent dates of the accidents, the date of first symptoms was used.

The annual incidence and mortality rates were calculated using the ratio of the absolute number of recorded accidents and the absolute number of recorded deaths, respectively, for the population at risk; and the ratio between the absolute number of recorded accidents and the absolute number of recorded deaths from scorpion envenomation was used to calculate the annual lethality rate. To calculate the average coefficients of incidence, mortality and lethality, we used the arithmetic mean of their annual coefficients.

The software packages TabWin32 3.6b, Epi Info 7.1.3.3 and Microsoft Excel 2010 were used to tabulate the data; Epi Info 7.1.3.3 was used to calculate the relative risk with its respective $95 \%$ confidence interval, based on the average lethality rate; TerraView 3.2.0 was used to produce the maps.

Primary data, simple measures of frequency and arithmetic means were employed to produce the description and analysis of the data.

The study was based on secondary data, without access to the patients' nominal data or anything else that could identify them. The ethical and legal requirements were followed as specified by Resolution 196/96 from the National Health Council.

\section{Results}

There was an increase in the number of reported cases in Brazil during the period of study, from 12,552 in 2000 to 64,027 in 2012 , a total of 482,616 cases. The same happened to the number of deaths, which rose from 13 in 2000 to 89 in 2012, with a maximum of 90 in 2009. During the period a total of 728 deaths were recorded (Table 1).

Table 1 Distribution of the absolute number of cases and deaths due to scorpion envenomation recorded in SINAN, and epidemiological indicators by year of occurrence, Brazil, 2000-2012

\begin{tabular}{|c|c|c|c|c|c|}
\hline Years & Cases & Deaths & $\begin{array}{c}\text { Incidence } \\
\text { rate }^{\mathrm{a}}\end{array}$ & $\begin{array}{c}\text { Mortality } \\
\text { rate }^{\mathrm{a}}\end{array}$ & $\begin{array}{l}\text { Lethality } \\
\text { rate (\%) }\end{array}$ \\
\hline 2000 & 12,552 & 13 & 7.4 & 0.008 & 0.10 \\
\hline 2001 & 17,996 & 38 & 10.4 & 0.022 & 0.21 \\
\hline 2002 & 22,500 & 49 & 12.9 & 0.028 & 0.22 \\
\hline 2003 & 24,280 & 49 & 13.7 & 0.028 & 0.20 \\
\hline 2004 & 29,991 & 40 & 16.7 & 0.022 & 0.13 \\
\hline 2005 & 35,531 & 45 & 19.3 & 0.024 & 0.13 \\
\hline 2006 & 37,032 & 24 & 19.8 & 0.013 & 0.06 \\
\hline 2007 & 37,261 & 61 & 19.7 & 0.032 & 0.16 \\
\hline 2008 & 40,236 & 85 & 21.2 & 0.045 & 0.21 \\
\hline 2009 & 50,350 & 90 & 26.3 & 0.047 & 0.18 \\
\hline 2010 & 51,698 & 67 & 27.1 & 0.035 & 0.13 \\
\hline 2011 & 59,162 & 78 & 29.3 & 0.041 & 0.14 \\
\hline 2012 & 64,027 & 89 & 31.3 & 0.046 & 0.15 \\
\hline Total & 482,616 & 728 & - & - & - \\
\hline Average $^{b}$ & - & - & 19.6 & 0.030 & 0.16 \\
\hline
\end{tabular}

Values corresponding to groups of 100,000 inhabitants. ${ }^{\mathrm{b}}$ Arithmetic mean. Data source: SINAN/SVS/MS. 
There was an increase of $323 \%$ in the incidence rate between 2000 and 2012, with an average for the period of 19.6 accidents per 100,000 inhabitants. The variation in the mortality rate was even higher, with an increase of $475 \%$ and an average of $0.030 / 100,000$ inhabitants. The lethality rate in Brazil had the minimum and maximum values of $0.06 \%$ in 2006 and $0.22 \%$ in 2002, reaching $0.15 \%$ in 2012 , with an average of $0.16 \%$ for the period (Table 1).

Males were more often affected than females both in the number of cases (50.7\%) and deaths (56.3\%), with a death risk that was 1.26 times higher. Most victims declared themselves to be black (44.7\%), the race/color that presented a higher frequency of deaths (50.5\%) and a death risk 1.37 times higher than that of whites. Most of the victims had between four and seven years of education (17.8\%). The race/color and education fields presented respective incompleteness percentages of $29.8 \%$ and $42.9 \%$. About half of the accidents (47\%) were in the age group 20-49, and the proportion of deaths was higher victims up to nine years old (53.9\%). Individuals of up to four years old had the highest risk of death, which was 10.09 times higher than that of victims aged 15 years or more. Table 2 describes the demographic characteristics and death risk from accidents during the period of study. The injured regions of the body were diverse, with fingers being the most frequent (24\%), followed by the feet (20\%), hands $(16.4 \%)$ and toes $(9.5 \%)$.

With respect to the accident zone, accidents historically have been more frequently recorded in urban areas (61.6\%), ranging from $43.8 \%$ in 2000 to $63.2 \%$ in 2012 . Northern Brazil alone accounted for about two-thirds of accidents in rural areas (62.8\%). Most of the recorded deaths in the country were from rural areas (57.4\%). The risk of death these areas was 2.92 times higher compared to urban areas (Table 2).

The accidents were less frequent in the months of June $(7.3 \%)$ and July (7.7\%), peaking in October (9.7\%), except in the northern region of the country, where the accidents peaked in May (10.1\%) and the lowest rate was registered in December (6.6\%) (Figure 1).

Taken together, the Northeast and Southeast presented the highest frequencies of cases (48\% and $40.7 \%$ ) and deaths (43.5\% and 44\%) (Figure 1A). The states of Minas Gerais (24.2\%), Bahia (16.8\%), São Paulo (13.3\%), Pernambuco (11.1\%) and Alagoas (8.7\%) had the highest frequency of cases, while deaths were most frequent in Minas Gerais (35.9\%), Bahia (30.4\%), Pernambuco (6.5\%), Pará (5.2\%), and São Paulo (3.4\%).

The Northeast and Southeast also presented the highest annual average incidence (Northeast 34.3/100,000 inhabitants; Southeast 19.1; North 12.4; Central West 11.1; South 2.9) and mortality (Northeast 0.047/100,000 inhabitants; Southeast 0.031; North 0.027; Central West
0.021; South 0.000) rates, whereas the North and Central West reported the highest annual average lethality rate (North 0.21\%; Central West $0.20 \%$; Southeast 0.16\%; Northeast $0.14 \%$; South $0.01 \%$ ) (Figure 2).

The states with the highest annual average incidence rates were Alagoas (105.9/100,000 inhabitants), Rio Grande do Norte (55.7/100,000 inhabitants), Pernambuco (47.7/ 100,000 inhabitants), Minas Gerais (46.4/100,000 inhabitants) and Bahia (44.6/100,000 inhabitants) (Figure 2A). The highest annual average mortality rates were Bahia (0.122/100,000 inhabitants), Minas Gerais (0.104/100,000 inhabitants), Espírito Santo (0.053/100,000 inhabitants), Pernambuco (0.041/100,000 inhabitants) and Pará (0.040/ 100,000 inhabitants) (Figure 2B), Finally, the highest annual average lethality rates were Rondônia (0.58\%), Rio de Janeiro (0.36\%), Bahia (0.29\%), Goiás $(0.28 \%)$ and Pará (0.24\%) (Figure 2C).

\section{Discussion}

The reports of scorpion stings quintupled in the period from 2000 to 2012 in Brazil, especially in the Northeast and Southeast regions, which contributed about $90 \%$ of the cases. Males, aged up to nine years old and rural areas were defined as the groups and areas for the greatest death risk, respectively.

The incidence of scorpion stings in different countries varies more widely than that found in the present study [5]. In the southern USA states of Texas and Arizona, the incidence rates are closer to the ones in Brazil, being $22 / 100,000$ inhabitants in both states. Nevertheless, the mortality rate in the southern USA is up to 140 times lower than the one presented in this study, according to Langley [20]. In Latin America, such accidents have been reported in several countries, such as Mexico, Colombia, Venezuela, Argentina and Chile [21-26].

The difference in the accident proportion between males and females was low, probably due to the similar risk exposures in the two genders, based on the characteristics of urban and domestic accident. Studies conducted in smaller groups and/or in different situations showed distinct proportions with regard to this variable, such as Lima et al. [27], in Natal (Rio Grande do Norte), with 1,698 accidents, of which $65 \%$ affected females; and Pardal et al. [28] in Santarém (Pará), with 72 accidents, of which $83.3 \%$ were male victims.

Economically active people were more affected, although the mortality rate in this group was lower compared to that of children under 4 years old. This characteristic was also observed in other studies in Brazilian states [29-32]. The emergency treatment of the injured people, mostly children, in reference service centers, is essential to reduce the accidents' lethality. Access to these centers is more difficult in rural areas, which is an important factor for the higher lethality in these regions. 
Table 2 Demographic characteristics of scorpionism cases registered in SINAN, Brazil, 2000-2012

\begin{tabular}{|c|c|c|c|c|c|c|c|}
\hline \multirow{2}{*}{$\begin{array}{l}\text { Demographic } \\
\text { data }\end{array}$} & \multicolumn{2}{|c|}{ Cases } & \multicolumn{2}{|c|}{ Deaths } & \multirow{2}{*}{$\begin{array}{l}\text { Lethality } \\
\text { rate }(\%)\end{array}$} & \multirow[t]{2}{*}{ RR (IC 95\%) } & \multirow[t]{2}{*}{$p$ value } \\
\hline & $n=482,616$ & $\%$ & $\mathrm{n}=728$ & $\%$ & & & \\
\hline \multicolumn{8}{|l|}{ Sex } \\
\hline Male & 244,593 & 50.7 & 410 & 56.3 & 0.17 & $1.26(1.09-1.45)$ & $p<0.05$ \\
\hline Female & 237,801 & 49.3 & 317 & 43.5 & 0.13 & 1 & - \\
\hline Ignored/Omitted & 222 & 0.0 & 1 & 0.1 & - & - & - \\
\hline \multicolumn{8}{|l|}{ Race/Color } \\
\hline White & 117,306 & 24.3 & 146 & 20.1 & 0.12 & 1 & - \\
\hline Black $^{a}$ & 215,938 & 44.7 & 368 & 50.5 & 0.17 & $1.37(1.13-1.66)$ & $p<0.05$ \\
\hline Yellow & 3,988 & 0.8 & 9 & 1.2 & 0.23 & $1.81(0.92-3.55)$ & $p>0.05$ \\
\hline Indigenous & 1,603 & 0.3 & 5 & 0.7 & 0.31 & $2.51(1.03-6.10)$ & $p>0.05$ \\
\hline Ignored/Omitted & 143,781 & 29.8 & 200 & 27.5 & 0.14 & - & - \\
\hline \multicolumn{8}{|l|}{ Education $^{\mathrm{b}}$} \\
\hline None & 17,810 & 3.7 & 16 & 2.2 & 0.09 & $1.39(0.78-2.45)$ & $p>0.05$ \\
\hline $1-3$ years & 53,716 & 11.1 & 82 & 11.3 & 0.15 & $2.36(1.64-3.39)$ & $p<0.05$ \\
\hline 4-7 years & 86,127 & 17.8 & 83 & 11.4 & 0.10 & $1.49(1.04-2.14)$ & $p<0.05$ \\
\hline 8 or more & 69,524 & 14.4 & 45 & 6.2 & 0.06 & 1 & - \\
\hline Not applicable & 48,603 & 10.1 & 314 & 43.1 & 0.65 & $9.98(7.30-13.64)$ & $p<0.05$ \\
\hline Ignored/Omitted & 206,836 & 42.9 & 188 & 25.8 & 0.09 & - & - \\
\hline \multicolumn{8}{|l|}{ Age $^{d}$} \\
\hline$<1-4$ & 33,038 & 6.8 & 234 & 32.1 & 0.71 & $10.09(8.46-12.02)$ & $p<0.05$ \\
\hline $5-9$ & 35,812 & 7.4 & 159 & 21.8 & 0.44 & $6.32(5.19-7.70)$ & $p<0.05$ \\
\hline $10-11$ & 39,123 & 8.1 & 72 & 9.9 & 0.18 & $2.62(2.02-3.40)$ & $p<0.05$ \\
\hline 15 and $+^{e}$ & 374,544 & 77.6 & 263 & 36.1 & 0.07 & 1 & - \\
\hline $15-19$ & 42,598 & 8.8 & 38 & 5.2 & 0.09 & - & - \\
\hline $20-49$ & 227,028 & 47.0 & 153 & 21.0 & 0.07 & - & - \\
\hline $50-64$ & 67,785 & 14.0 & 45 & 6.2 & 0.07 & - & - \\
\hline $65-79$ & 31,242 & 6.5 & 21 & 2.9 & 0.07 & - & - \\
\hline 80 and + & 5,891 & 1.2 & 6 & 0.8 & 0.10 & - & - \\
\hline Ignored/Omitted & 99 & 0.0 & 0 & 0.0 & 0.00 & - & - \\
\hline \multicolumn{8}{|l|}{ Accident zone } \\
\hline Urban Area & 297,595 & 61.7 & 281 & 38.6 & 0.09 & 1 & - \\
\hline Rural Area & 151,579 & 31.4 & 419 & 57.4 & 0.28 & $2.92(2.51-3.40)$ & $p<0.05$ \\
\hline Ignored/Omitted & 33,442 & 6.9 & 28 & 3.8 & 0.08 & - & - \\
\hline
\end{tabular}

${ }^{\mathrm{a}}$ Race/color black = summation of skin colors black and brown [19]. ${ }^{\mathrm{b}}$ Education in complete years of study. ${ }^{\mathrm{C}}$ Variable is automatically filled when the notified case is less than seven years old. ${ }^{d}$ Age in years. ${ }^{e}$ Age " 15 and $+"=$ summation of ages 15-19, 20-49, 50-64, 65-79, 80 and + . Data Source: SINAN/SVS/MS.

According to a study performed by Nunes et al. [33], household chores, such as handling clothes and wet cloths, expose people to the risk of scorpion accidents, which could explain the higher frequency of accidents in the hands and fingers (40.4\%) and feet and toes (29.5\%). There are several studies showing such results [34-37].

The growing process of urbanization, poor household conditions and the high ecological plasticity of some medically important scorpion species, such as $T$. serrulatus, referred to as the greatest cause of serious accidents in Brazil, and T. stigmurus, have altered the epidemiology of accidents, as evidenced in previous studies $[13,38,39]$. The increasing records of urban accidents over the years corroborate this fact, although most deaths still occur in rural areas. In this context, the most vulnerable socioeconomic populations, people who identify themselves as black and those with lower education levels (between four and seven years of study, equivalent to elementary school), were the 

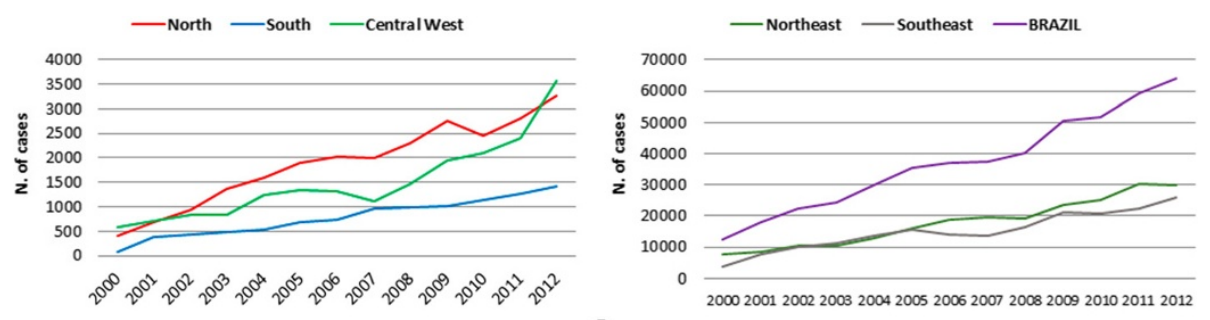

A
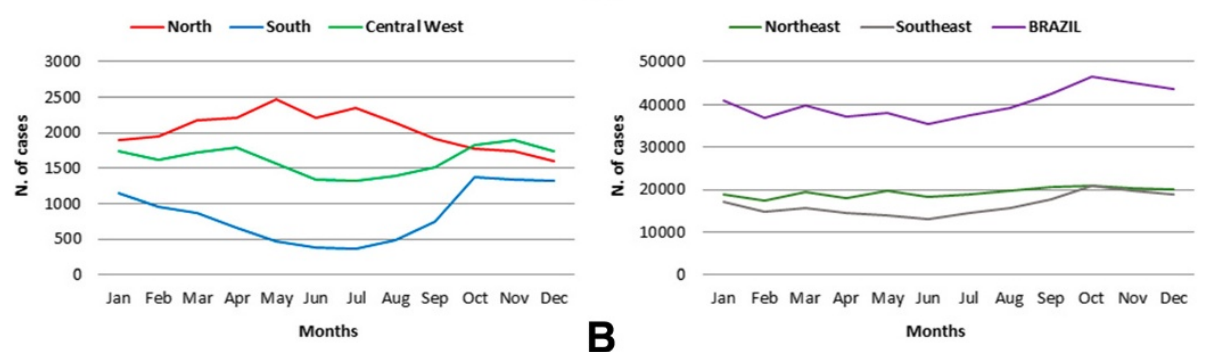

Figure 1 Temporal distribution of absolute number of cases of accidents with scorpions by region in Brazil by (A) year and (B) month of the accident, Brazil, 2000-2012.

most affected. This relation, although described in other studies, needs to be elucidated in Brazil due to possible errors in the completion of the race/color and education variables, which are self-declared [35,40].

The most populous regions, the Northeast and Southeast, containing about $70 \%$ of the population, present respective urbanization degrees of $84.4 \%$ and $73.1 \%$ [38]. These characteristics, combined with the presence of the perfectly adapted scorpion, are favoring the high incidence rates in these regions. According to Porto and Brazil [39], in tropical countries scorpions are more active in warmer and wetter months of the year, which was also observed in the present study, with an elevated number of accidents at these times, except for the northern region, whose climatic characteristics differ from those in the rest of the country. This feature was discussed by Pardal et al. [28] in the municipality of Santarém (Pará), where the highest incidence of scorpion accidents occurred during the months from March to August, confirming the different seasonality in northern locations.

There are several factors that may be linked to deaths from scorpion envenomation including scorpion species causing the accident, lack of access to health care and quality services, and ignorance among the population about the importance of medical care in case of accidents by venomous animals. A study performed by Guerra et al. [41] highlights the direct relationship between risk of death and severe cases, and between the time elapsed from the accident to treatment.

Despite the dilution of possible registry errors by virtue of the large number of cases analyzed in the present work, the study was based on a secondary data source supplied by different professionals, allowing different interpretations of the SINAN FNI at the time of its completion. The underreporting is a reality for this health problem, but because of the lack of national comparison systems, there is no other means to measure its magnitude.

The "race/color" and "Education" FNI fields, completed by the victims' self-declaration, are tenuous because of possible biases in the victims' definition when declaring their race/color, and in determining the years of study, leading therefore to the possibility of errors in the records, as well as a high degree of incompleteness of these fields.

\section{Conclusions}

The epidemiological changes described in this study highlight the need for intensifying the actions of health surveillance of scorpion accidents in Brazil and also studies that can establish associations between these accidents and environmental risk factors, taking into account regional differences. Additionally, enhancement of the health services is essential to decrease the lethality of these accidents, which constitute a public health problem, especially for the most vulnerable groups.

\section{Ethics committee approval}

All ethical and legal requirements were observed in the present study, as recommended by the Resolution 196/96 from the National Health Council. 

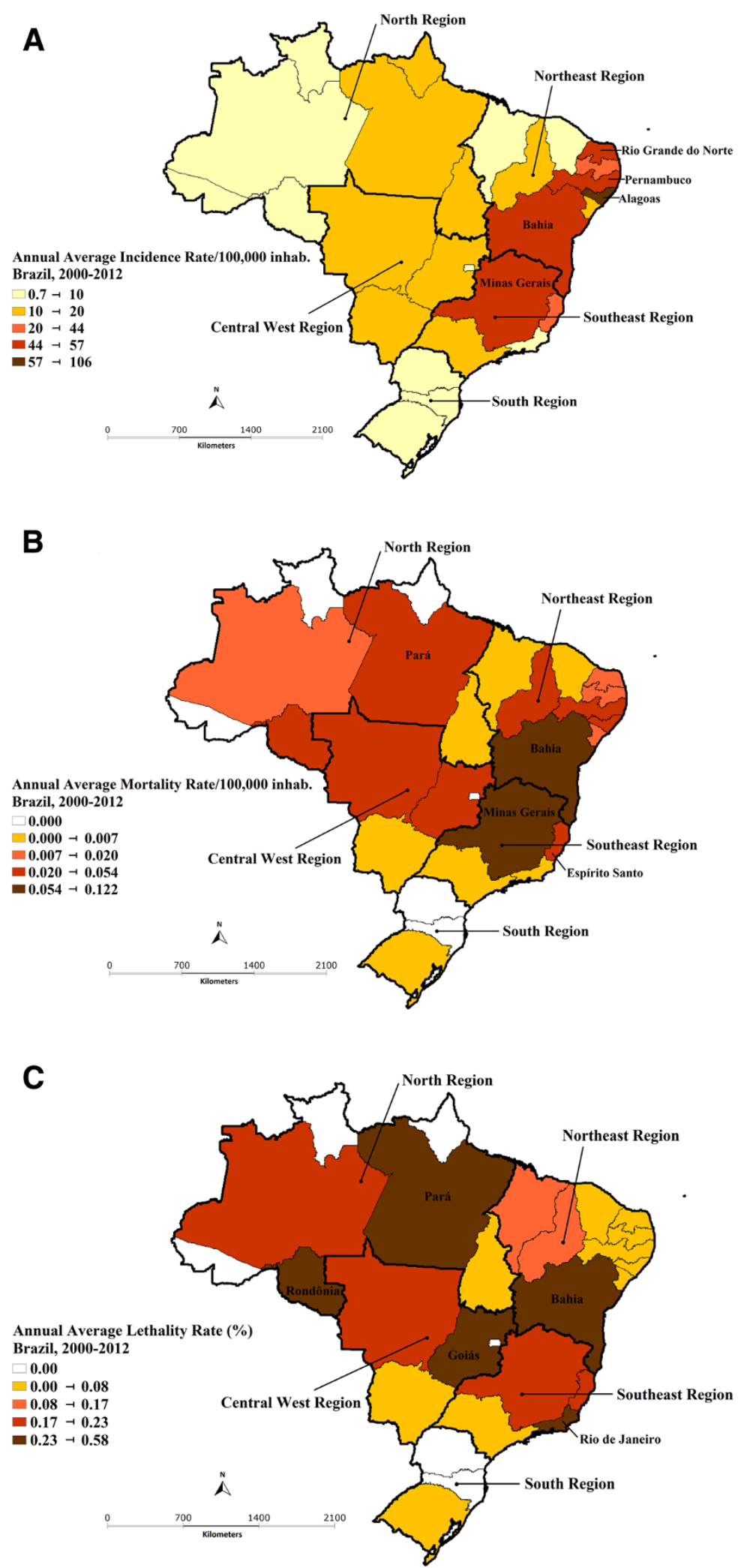

Figure 2 (A) Annual average incidence, (B) mortality and (C) lethality rates of scorpion envenomation in Brazil, 2000-2012. 


\section{Competing interests}

The authors declare that they have no competing interests.

\section{Authors' contributions}

GCR conceived the study, participated in the design, performed the statistical analysis and helped to draft the manuscript. VLPJ participated in the study design, performed the statistical analysis and provided technical support and scientific discussions. Both authors read and approved the fina manuscript.

\section{Author details}

'Programa de Pós-Graduação em Saúde Coletiva, Faculdade de Ciências da Saúde, Universidade de Brasília, Brasília, Distrito Federal, Brasil. ${ }^{2}$ Programa Nacional de Controle de Acidentes por Animais Peçonhentos, Ministério da Saúde, Brasília, Distrito Federal, Brasil. ${ }^{3}$ Laboratório de Epidemiologia e Vigilância em Saúde, Fiocruz, Brasília, Distrito Federal, Brasil.

Received: 10 June 2014 Accepted: 6 October 2014

Published: 15 October 2014

\section{References}

1. Secretaria de Vigilância em Saúde. Departamento de Vigilância Epidemiológica: Manual de Controle de Escorpiões, Série B. Brasilia: Ministério da Saúde; 2009:72.

2. Lourenço WR, Cuellar O: Scorpions, scorpionism, life history strategies and parthenogenesis. J Venom Anim Toxins 1995, 1(2):51-62 [http://www. scielo.br/scielo.php?script=sci_arttext\&pid=S0104-79301995000200002]

3. Lourenço WR: Parthenogenesis in scorpions: some history - new data. J Venom Anim Toxins Incl Trop Dis 2008, 14(1):19-44 [http://www.scielo.br/ scielo.php?pid=S1678-91992008000100003\&script=sci_arttext]

4. Cupo P, Jurca M, Azevedo-Marques MM, Oliveira JSM, Hering SE: Severe scorpion envenomation in Brazil. Clinical, laboratory and anatomopathological aspects. Rev Inst Med Trop Sao Paulo 1994, 36(1):67-76.

5. Chippaux JP, Goyffon M: Epidemiology of scorpionism: a global appraisal. Acta Trop 2008, 107(2):71-79.

6. Albuquerque CMR, Barbosa MO, lannuzzi L: Tityus stigmurus (Thorell, 1876) (Scorpiones; Buthidae): response to chemical control and understanding of scorpionism among the population. Rev Soc Bras Med Trop 2009, 42(3):255-259.

7. Os escorpiões de importância médica e seus venenos. In Os Escorpiões. Edited by Porto TJ, Brazil TK. Salvador: EDUFBA; 2011:15-32.

8. World Health Organization: Rabies and Envenomings: A Neglected Public Health Issue: Report of a Consultative Meeting. Geneva: World Health Organization; 2007.

9. Ministério da Saúde. Gabinete do Ministro: Portaria n.1271, de 06 de Junho de 2014. Define a Lista Nacional de Notificação Compulsória de Doenças, Agravos e Eventos de Saúde Pública nos Serviços de Saúde Públicos e Privados em Todo o Território nacional, nos Termos do Anexo, e dá Outras Providências, Seção 1. Braślia: Diário Oficial da União; 2014:67.

10. Araújo FAA, Santalúcia M, Cabral RF: Epidemiologia dos acidentes por animais peçonhentos. In Animais Peçonhentos no Brasil: Biologia, Clínica e Terapêutica dos Acidentes. Edited by Cardoso JLC, França FOS, Wen FH, Málaque CMS, Haddad V Jr. São Paulo: Sarvier; 2003:6-12.

11. de Oliveira RC, Wen FH, Sifuentes DN: Epidemiologia dos acidentes por animais peçonhentos. In Animais Peçonhentos no Brasil: Biologia, Clínica e Terapêutica dos Acidentes. Edited by Cardoso JLC, França FOS, Wen FH, Málaque CMS, Haddad V Jr. São Paulo: Sarvier; 2009:6-21.

12. Porto TJ, Brazil TK, Souza CAR: Diversidade de escorpiões no Brasil. In Os Escorpiōes. Edited by Brazil TK, Porto TJ. Salvador: EDUFBA; 2011:47-64.

13. Cupo P, Azevedo-Marques MM, Hering SE: Escorpionismo. In Animais Peçonhentos no Brasil: Biologia, Clínica e Terapêutica dos Acidentes. Edited by Cardoso JLC, França FOS, Wen FH, Málaque CMS, Haddad V Jr. São Paulo: Sarvier; 2009:214-224.

14. Secretaria de Vigilância em Saúde: Acidentes por animais peçonhentos Caderno 15. In Guia de Vigilância Epidemiológica, Série A. 7a ediçãoth edition. Brasília: Ministério da Saúde; 2009.

15. IBGE - Instituto Brasileiro de Geografia e Estatística. [http://www.ibge.gov.br]. População [accessed on March 20th, 2014].

16. Fundação Nacional de Saúde: Manual de Diagnóstico e Tratamento de Acidentes por Animais Peçonhentos. $2^{\circ}$ edição revisadath edition. Brasília: Ministério da Saúde; 2001:120.
17. Mebs D: Venomous and Poisonous Animals: A Handbook for Biologists, Toxicologists and Toxinologists, Physicians and Pharmacists. Stuttgart: Medpharm Scientific Publishers; 2002:172-178.

18. Campolina D, Guerra CMN, Guerra SD, Dias MB, Andrade Filho A: Escorpionismo. In Toxicologia na Prática Clínica. $2^{\circ}$ ediçãoth edition. Edited by Filho AA, Campolina D, Dias MB. Belo Horizonte: Folium; 2013:295-319.

19. Secretaria de Gestão Estratégica e Participativa: Política Nacional de Saúde Integral da População Negra. Brasília: Ministério da Saúde; 2007.

20. Langley RL: Animal-related fatalities in the United States-an update. Wilderness Environ Med 2005, 16(2):67-74.

21. Dehesa-Dávila M, Possani LD: Scorpionism and serotherapy in Mexico. Toxicon 1994, 32(9):1015-1018.

22. Chowell G, Díaz-Dueñas P, Bustos-Saldaña R, Mireles AA, Fet V: Epidemiological and clinical characteristics of scorpionism in Colima, Mexico (2000-2001). Toxicon 2006, 47(7):738-753.

23. Otero R, Navio E, Céspedes FA, Núñez MJ, Lozano L, Moscoso ER, Matallana C, Arsuza NB, García J, Fernández D, Rodas JH, Rodríguez OJ, Zuleta JE, Gómez JP, Saldarriaga M, Quintana JC, Núñez V, Cárdenas S, Barona J, Valderrama R, Paz N, Díaz A, Rodríguez OL, Martínez MD, Maturana R, Beltrán LE, Mesa MB, Paniagua J, Flórez E, Lourenço WR: Scorpion envenoming in two regions of Colombia: clinical, epidemiological and therapeutic aspects. Trans R Soc Trop Med Hyg 2004, 98(12):742-750.

24. De Sousa L, Parrilla-Alvarez PE, Quiroga M: An epidemiological review of scorpion stings in Venezuela: the Northeastern region. J Venom Anim Toxins 2000, 6(2):128-166 [http://www.scielo.br/scielo.php?pid=s010479302000000200002\&script=sci_arttext]

25. de Roodt AR, García SI, Salomón OD, Segre L, Dolab JA, Funes RF, de Titto EH: Epidemiological and clinical aspects of scorpionism by Tityus trivittatus in Argentina. Toxicon 2003, 41(8):971-977.

26. Schenone Fernández H, Fontecilla J: Brotes epidémicos de picaduras de escorpión en habitantes de viviendas urbanas de construcción reciente. Bol Chil Parasitol 1998, 53(1/2):35-37.

27. Lima ALM, Lima JA, Souto MCS, Lopes TFC, Torres UPS, Maciel ACC: Spatial distribution and epidemiological profile of scorpion accidents in Natal/RN. Con Scientiae Saúde 2011, 10(4):627-633.

28. Pardal PPO, Castro LC, Jennings E, Pardal JSO, Monteiro MRCC: Aspectos epidemiológicos e clínicos do escorpionismo na região de Santarém, Estado do Pará. Bras Rev Soc Bras Med Trop 2003, 36(3):349-353.

29. Soares MRM, Azevedo CS, De Maria M: Escorpionismo em Belo Horizonte, MG: um estudo retrospectivo. Rev Soc Bras Med Trop 2002, 35(4):359-363.

30. Ribeiro $L A$, Rodrigues $L$, Jorge MT: Aspectos clínicos e epidemiológicos do envenenamento por escorpiões em São Paulo e municípios próximos. Rev Patol Trop 2001, 30(1):83-92.

31. Albuquerque ICS, Albuquerque HN, Albuquerque EF, Nogueira AS, Cavalcanti MLF: Escorpionismo em Campina Grande-PB. Rev Biol Ciênc Terra 2004, 4(1):2-9.

32. Maestri Neto A, Guedes AB, Carmo SF, Chalkidis HM, Coelho JS, Pardal PPO: Aspectos do escorpionismo no Estado do Pará-Brasil. Rev Para Med 2008, 22(1):49-55.

33. Nunes CS, Bevilacqua PD, Jardim CCG: Aspectos demográficos e espaciais dos acidentes escorpiônicos no Distrito Sanitário Noroeste, município de Belo Horizonte, Minas Gerais, 1993 a 1996. Cad Saude Publica 2000, 16(1):213-223.

34. Horta FMB, Caldeira AP, Sares JA: Escorpionismo em crianças e adolescentes: aspectos clínicos e epidemiológicos de pacientes hospitalizados. Rev Soc Bras Med Trop 2007, 40(3):351-353.

35. Barbosa AD, Magalhães DF, Silva JA, Silva MX, Cardoso MFEC, Meneses JNC, Cunha MCM: Caracterização dos acidentes escorpiônicos em Belo Horizonte, Minas Gerais, Brasil, 2005 a 2009. Cad Saude Publica 2012, 28(9):1785-1789.

36. Oliveira HFA, Lopes YACF, Barros RM, Vieira AA, Leite RS: Epidemiologia dos acidentes escorpiônicos ocorridos na Paraíba - Nordeste do Brasil. Rev Biol Farm 2012, 8(2):86-96.

37. Costa LSOC: Aspectos epidemiológicos do escorpionismo na região de Santarém, Estado do Pará, Brasil. Rev Colombiana Cienc Anim 2012, 4(1):59-68.

38. Ministério do Planejamento, Orçamento e Gestão. Fundação Instituto Brasileiro de Geografia e Estatística [IBGE]: Sinopse do Censo Demográfico 2010. In Relatório de Gestão. Rio de Janeiro: IBGE; 2011.

39. Porto TJ, Brazil TK: Quem são os escorpiões? In Os Escorpiões. Edited by Brazil TK, Porto TJ. Salvador: EDUFBA; 2011:15-32. 
40. Borges MAFS: A vigilância Epidemiológica dos Acidentes por Escorpiões: Uma Abordagem no Campo da Saúde Coletiva. Dissertação. São Paulo: Escola de enfermagem. Universidade de São Paulo; 2004.

41. Guerra CM, Carvalho LF, Colosimo EA, Freire HB: Analysis of variables related to fatal outcomes of scorpion envenomation in children and adolescents in the State of Minas Gerais, Brazil, from 2001 to 2005. J Pediatr (Rio J) 2008, 84(6):509-515.

doi:10.1186/1678-9199-20-46

Cite this article as: Reckziegel and Pinto: Scorpionism in Brazil in the years 2000 to 2012. Journal of Venomous Animals and Toxins including Tropical Diseases 2014 20:46.

\section{Submit your next manuscript to BioMed Central and take full advantage of:}

- Convenient online submission

- Thorough peer review

- No space constraints or color figure charges

- Immediate publication on acceptance

- Inclusion in PubMed, CAS, Scopus and Google Scholar

- Research which is freely available for redistribution 